\title{
EFEK PENGGUNAAN ZAT PEWARNA Erythrosine TERHADAP KADAR T3 DAN T4 SERUM PADA TIKUS GALUR WISTAR
}

\author{
Asterina, Elmatris Sy, Yustini Alioes \\ Bagian Kimia Fakultas Kedokteran Universitas Andalas \\ email : asterinadewanti@gmail.com
}

\begin{abstract}
Abstrak
Zat pewarna sintetis erythrosine berdasarkan struktur kimianya terkandung senyawa yodium, maka dapat dikatakan secara substansial asupan makanan yang mengandung erythrosine merupakan asupan yodium. Penggunaan zat pewarna erythrosine dalam waktu lama dan kadar diatas ambang batas tentu akan memberikan kontribusi kelebihan asupan yodium dan akan berdampak terhadap kadar T3 dan T4 dalam serum.

Penelitian ini bertujuan untuk mengetahui Efek Penggunaan Zat Pewarna Erythrosine terhadap Kadar T3 dan T4 Serum pada Tikus galur Wistar, yang dilakukan dari bulan April sampai bulan November 2010. Penelitian ini dilakukan di laboratorium Farmasi Unand dan Laboratorium Biokimia Fakultas Kedokteran Unand . Jenis penelitian yang digunakan adalah Eksperimental dengan jumlah sampel sebanyak 21. Hasil penelitian menunjukan terdapat kecendrungan penurunan T3 dan T4. Kesimpulan : terdapat efek pemberian Erythrosine 300 ppm, 600 ppm hingga 1\% pada waktu 3 minggu terhadap kadar T3 dan T4, secara statistic terdapat penurunan yang bermakna dengan nilai $p=0,018$ dan $p=0,012$ bila dibandingkan dengan kontrol. Tidak terdapat pengaruh lama waktu paparan zat pewarna erythrosine terhadap nilai T3, yang secara statistic tidak terdapat penurunan yang bermakna dengan $\mathrm{p}=0,062$, bila dibandingkan terhadap kontrol. Terdapat pengaruh lama waktu paparan zat pewarna erythrosine terhadap nilai T4 , yang secara statistic terdapat penurunan yang bermakna dengan $p=0,041$, bila dibandingkan terhadap kontrol.
\end{abstract}

Kata kunci : Erythrosine, T3, T4

\section{Abstract}

The synthetic dyes, erythrosine based on their chemical structure contain iodine compound, then they can be said substantially as food intake containing erythrosine is iodine uptake. The utility eryhthrosine in a long time with certain over thres hold will provide to contribute iodine uptake exceed and impact to serum $\mathrm{T} 3$ and $\mathrm{T} 4$.

This research aim to know the effect of using erythrosine dye to serum T3 and T4 in Galur Wistar mice, performed from April to November 2010. This research is performe in Laboratory of Farmacy of Andalas University and Biochemical laboratory of Medical Faculty, Andalas University. Type of study used is 
Experimental study with 21. samples. Result indicate that there is tendency of decreasing T3 and T4.

Conclusion: there are administering effect of 300 ppm, 600 ppm Erythrosine until $1 \%$ for three weeks to $\mathrm{T} 3$ and $\mathrm{T} 4$, respectively. Statistically, there are significantly decreasing with value $\mathrm{p}=0,018$ and $\mathrm{p}=0,012$ respectively, than control. There is not effect of expose time of Erythrosine to T3, which statistically is no significantly declining by $p=0,062$, than control. There are effect of expose time of eryhrosine to T4 level, which statistically there is declining significantly with $\mathrm{p}=0,041$, than control.

Key word : Erythrosine, T3, T4. 


\section{Pendahuluan}

Penggunaan zat warna sintetis yang sesuai dengan anjuran, jika digunakan secara terus menerus dapat memberikan dampak negatif terhadap kesehatan manusia. Pewarna sintetis dapat memberikan dampak kesehatan seperti; tartazin dapat menyebabkan alergi, asma dan hiperaktif pada anak. Salah satu golongan zat pewarna sintetis yaitu Erythrosine bersifat karsinogenik, yang telah dilakukan di Jepang terhadap ikan. Selain bersifat karsinogenik, bahan ini dapat juga bersifat toksisitas akut dan hipertropi kelenjar gondok, hiperplasi kelenjar gondok dan meningkatkan insiden neoplsma kelenjar gondok. ${ }^{(1)}$ Hipertropi kelenjer gondok diindikasikan dengan meningkatnya kadar T3 dan T4 di dalam serum. Pembesaran kelenjer gondok (tiroid) didapatkan oleh peningkatan kadar TSH (thiroid stimulating hormon), serta peningkatan kadar T3 dan T4 didalam serum. Peningkatan sekresi hormon tiroid tersebut dapat mengkompensasi resistensi relatif jaringan perifer terhadap hormon tiroid, maka ini dapat memperlihatkan tanda-tanda hiperthiroid. Apabila tidak maka pasien dapat memperlihatkan gejala tanda hypotiroid.

Zat pewarna yang merupakan bahan tambahan pangan (BTP) dapat memperbaiki atau memberi warna pada makanan. Penggunaan harus secukup-nya saja, namun ada pula pewarna yang memang beracun, bahkan ada zat pewarna tekstil digunakan untuk pewarna makanan. Hal ini sangat ber-bahaya karena adanya residu logam berat yang dapat meracuni ginjal. Jika penggunaan bahan tambahan pangan (BTP) tersebut secara terus-menerus dan melebihi dari kadar yang sudah ditentukan, maka akan terakumulasi (tertimbun) dalam tubuh yang pada akhirnya dapat merusak jaringan atau organ tertentu. Sebagai contoh karena tingginya kadar bahan pewarna, maka hati akan bekerja keras untuk merombaknya agar dapat dikeluarkan dari hati. Dari hati, kemudian masuk dalam sistem peredaran darah yang selanjutnya menuju ginjal. Ginjal harus bekerja keras mengekskresikan bahan tersebut keluar tubuh. Hati mempunyai kemampuan yang terbatas untuk merombak zat pewarna, Akibatnya ada yang tertimbun di hati dan mengganggu fungsi ginjal. BTP tersebut tidak saja mengganggu kesehatan jika tera-kumulasi, tetapi juga dapat menyebab-kan nilai gizi pada makanan tertentu berkurang. (2)

Zat pewarna Erythrosine juga telah digunakan didalam makanan ringan seperti kripik balado yang dijumpai dalam penelitian Analisis kualitatif dan Kuantitatif Zat Pewarna Pada Kripik Balado Yang Beredar di Bukittinggi. Hasil penelitian menunjuk-kan dari 18 sampel yang dianalisis terdapat $75 \%$ menggunakan zat pewarna sintetis merah yaitu Ponceu $4 R$ dan Erythrosine. Ternyata dari kedua zat pewarna ini $73,3 \%$ adalah Erythrosine. Kadar zat pewarna yang digunakan terhadap sampel ternyata $40 \%$ menggunakan zat pewarna yang melebihi ketentuan Dep.Kes.RI. ${ }^{(3)}$

Efek toksik zat pewarna erythrosine ini telah diteliti pada tikus jantan oleh Abdel Azis A.H et all, temuan menunjukkan bahwa erythrosine dalam dosis $68 \mathrm{mg} / \mathrm{kg}$ dan $136 \mathrm{mg} / \mathrm{kg}$ yang digunakan, memberikan efek toksik pada spermatogenesis dan pada gilirannya mungkin akan mempengaruhi fungsi kinerja reproduksi dari tikus jantan. ${ }^{(4)}$ 
Penelitian penggunaan erythrosine juga telah dilakukan oleh Anthonius. Jenings, Sorell,L et all terhadap tikus percobaan, didapatkan temuan yang menunjukkan bahwa pemberian Erythrosine hingga 4\% selama 30 bulan menyebabkan terjadinya insiden peningkatan adenomos dan adenokarsinoma, T3 \& T4 serum meningkat. ${ }^{(5)}$

Erythrosine bila dilihat dari senyawa kimianya adalah 2-(6hidroxy-2,4,5,7-tetra iodo-3-okxoxanthen-9-yl). Dapat dikatakan asupan makanan dan obat-obatan yang mengandung erythro-sine bisa berkontribusi secara substansial sebagai diet asupan yodium. Jika asupan yodium meningkat dan berlangsung kronik dapat mengindikasikan terjadinya hipotirodisme. Kadar optimal asupan yodium untuk mencegah kelainan tiroid merupakan rentangan yang sempit yaitu asupan yodium yang dianjurkan sehari berkisar $150 \mu \mathrm{g}$ untuk orang dewasa. Bahkan dengan iodisasi garam yang berhati-hatipun terjadi peningkatan insidence rate hipertirodisme. ${ }^{(6)} \quad$ Kelebihan dan kekurangan yodium dapat menyebabkan gondok. Faktor lainnya baik tergolong faktor lingkungan maupun genetik dapat berperanan patofisiologis gondok. ${ }^{(7)}$ Kemungkinan efek samping yang ditimbulkan akibat kelebihan iodium adalah: 1 . Gondok iodida dan hipotirodisme yang diinduksi oleh kelebihan yodium, 2. hipertirodisme yang diinduksi oleh kelebihan yodium (Iodium-Induced Hypertirodism, IIH), 3.Tiroiditis yang diinduksi oleh yodium, 4. Kanker tiroid.

Mengingat zat pewarna sintetis erythrosine berdasarkan struktur kimia-nya terkandung senyawa yodium, maka dapat dikatakan secara substansial asupan makanan yang mengandung erythrosine merupakan asupan yodium. Penggunaan zat pewarna erythrosine dalam waktu lama dan kadar erythrosine diatas ambang batas tentu akan memberikan kontribusi kelebihan asupan yodium. Kelebihan asupan yodium akan berdampak terhadap kadar T3 dan T4 dalam serum.

Rumusan Masalah : Apakah pemberian 300ppm, 600ppm dan 1\% yang telah dikonversikan sesuai berat badan tikus, dapat mempengaruhi T3, dan T4 serum tikus

Tujuan Umum Mengetahui efek penggunaan zat pewarna erytrosine terhadap kadar T3 dan T4 serum pada Tikus Galur wistar.

\section{Tujuan Khusus}

1. Mengetahui kadar $\mathrm{T} 3$ dan $\mathrm{T} 4$ serum akibat paparan zat pewarna Erythrosine 300ppm, $600 \mathrm{ppm}$ dan $1 \%$ erythrosine) dengan lama waktu konstan (3 minggu) pada Tikus Galur wistar.

2. Mengetahui T3 dan T4 serum akibat pengaruh lama waktu pemaparan pada konsentrasi maksimum erythrosine (1 minggu, 2 minggu dan 3 minggu) pada Tikus Galur Wistar.

3. Mengetahui perbedaan antara kadar T3 dan T4 serum akibat paparan zat pewarna erythrosine dengan kadar T3, T4 dari Tikus Galur Wistar terhadap kontrol.

\section{Manfaat Penelitian}

1. Hasil penelitian ini diharapkan dapat memberikan gambaran 
informasi bahaya/dampak penggunaan zat pewarna erythrosine terhadap T3 dan T4.

2. Sebagai masukan bagi Dinas Kesehatan dan Badan POM serta Departemen Perindustrian dan Perdagangan sehingga dapat dijadikan pedoman untuk mendorong perkembangan kualitas makanan oleh produsen.

\section{Metode Penelitian Jenis Penelitian}

Penelitian ini adalah penelitian eksperimental dengan Tikus Galur Wistar sebagai objek penelitian.

\section{Waktu dan Tempat Penelitian}

Penelitian ini dilakukan di Laboratorium Biokimia Fakultas Kedokteran dan Laboratorium Farmasi Universitas Andalas pada bulan April - November 2010.

\section{Populasi, Sampel, Besar Sampel dan Tekhnik Pengambilan Sampel}

Populasi adalah Tikus galur wistar, umur $\pm 2,5-3$ bulan dan berat badan 200-250 gram. Sampel diambil secara acak (simple random sampling) dari populasi dan penelitian ini terdiri atas 3 kelompok yakni:

1. Kelompok A (Kontrol)

2. Kelompok B (Perlakuan pada variasi konsentrasi erythrosine, dengan lama pemberian 2 builan terdapat 3 kali perlakuan).

3. Kelompok C (Perlakuan pada variasi waktu pemaparan,Terdapat 3 kali perlakuan).

Dilakukan analisis terhadap Kadar T3,T4 dari tikus galur wistar.

Jumlah ulangan untuk setiap perlakuan ditentukan dengan menggunakan rumus Gomez :

$$
(\mathrm{t}-1)(\mathrm{r}-1) \geq 15
$$

Keterangan :

$\mathrm{t}=$ jumlah perlakuan $=$ jumlah ulangan (jumlah sampel tiap perlakuan).

Pada penelitian ini jumlah ulangan yang didapat adalah : $(7-1)(\mathrm{r}-1) \geq$ 15 -----------r $\geq 3$. Pada penelitian ini ditetapkan ulangan sebanyak 3 kali, sehingga jumlah sampel adalah $7 \times 3=$ 21 ekor tikus.

\section{Analisa Data}

Data yang diperoleh dikumpulkan dan dianalisa dengan statistik, dengan menggunakan ANOVA.

\section{Hasil dan Pembahasan Hasil}

Berdasarkan penelitian yang telah dilakukan dalam waktu hanya 3 minggu didapat hasil dengan rincian sebagai berikut seperti terlihat pada tabel :

Tabel 1. Kadar T3 dan T4 serum pada tikus sebelum terpapar zat pewarna Erythrosine (sebagai kontrol)

\begin{tabular}{llcccc}
\hline No & Kelompok Kontrol & \multicolumn{2}{c}{ Kadar } & \multicolumn{2}{c}{ Nilai Rata - rata } \\
\cline { 3 - 6 } & & $\mathbf{T 3}(\boldsymbol{\mu l} / \mathbf{d l} \mathbf{)}$ & $\mathbf{T 4}(\boldsymbol{\mu l} / \mathbf{d l})$ & $\mathbf{T 3}(\boldsymbol{\mu l} / \mathbf{d l})$ & $\mathbf{T 4}(\boldsymbol{\mu l} / \mathbf{d l})$ \\
\hline 1. & K1 & 1.25 & 6.49 & 1.135 & 6.13 \\
\hline
\end{tabular}


Pada tabel 1 di atas dapat dilihat nilai rata-rata kadar T3 dan T4 serum tikus Galur Wistar adalah 1,135 dan 6,13.

Tabel 2. Kadar T3 serum akibat paparan Zat pewarna Erythrosine 300 ppm, 600 ppm hingga $1 \%$ dengan lama waktu konstan ( 3 minggu) pada tikus galur wistar.

\begin{tabular}{llcccc}
\hline \multirow{2}{*}{ No. } & Kelompok & \multicolumn{2}{c}{ Kadar T3 $(\boldsymbol{\mu l} / \mathbf{d l})$} & Nilai Rata-rata & P \\
\cline { 3 - 4 } & & $\mathbf{1}$ & $\mathbf{2}$ & & \\
\hline 1. & Kontrol & 1.25 & 1.02 & 1.135 & \\
2. & E300 & 0.698 & 0.962 & 0.695 & 0.018 \\
3. & E600 & 0.721 & 0.727 & 0.734 & \\
4. & E1\% & 0.852 & 0.852 & 0.845 & \\
\hline
\end{tabular}

Tabel 2 memperlihatkan penurunan rerata $\mathrm{T} 3$ serum tikus akibat paparan erythrosine. Hasil analisis statistik Anova didapatkan nilai $\mathrm{p}=0,018 \quad(\mathrm{p}<0,05)$. Ini menunjukkan bahwa terdapat per- bedaan bermakna antara kelompok kontrol (K) terhadap kelompok perlakuan (300 ppm, 600 ppm dan 1\%). Analisis statistik dapat dilanjutkan dengan Post Hoc Tests Multiple Comparison.

Tabel 3. Analisis Post Hoc Tests antara kelompok terhadap kadar T3 setelah pemberian Erythrosine

\begin{tabular}{cccc}
\hline Variabel & \multicolumn{2}{c}{ Kelompok } & p \\
\hline & Kontrol & E300 & 0.034 \\
Kadar T3 setelah & & E600 & 0,044 \\
pemberian Erythrosine & \multirow{2}{*}{ E300 } & E 1\% & 0,142 \\
& & E600 & 1,000 \\
& E600 & E 1\% & 0,838 \\
& & E 1\% & 1,000 \\
\hline
\end{tabular}

Tabel 3 memperlihatkan bahwa terdapat perbedaan yang bermakna antara kontrol dengan paparan zat pewarna Erythtrosine $300 \mathrm{ppm}$ dan $600 \mathrm{ppm}(\mathrm{p}<0,005)$ dan terdapat perbedaan yang tidak bermakna antara kontrol dengan pemberian Erythrosine $1 \%(\mathrm{p}>0.0,05)$ terhadap kadar T3.

Tabel 4. Kadar T3 serum akibat paparan zat pewarna Erythrosine 1\% dengan lama waktu yang bervariasi (1,2,3 minggu) pada tikus galur wistar.

\begin{tabular}{llcccc}
\hline No. & Kelompok & \multicolumn{2}{c}{ Kadar $\mathbf{T 3}(\boldsymbol{\mu l} / \mathbf{d l})$} & $\begin{array}{c}\text { Nilai Rata-rata } \\
\text { T3 }(\boldsymbol{\mu l} / \mathbf{d l})\end{array}$ & $\mathbf{P}$ \\
& & $\mathbf{1}$ & $\mathbf{2}$ & & \\
\hline 1. & Kontrol & 1.25 & 1.02 & 1.135 & \\
2. & E1 & 0.878 & 0.866 & 0.872 & 0.062 \\
3. & E2 & 0.859 & 0.862 & 0.861 & \\
4. & E3 & 0.838 & 0.852 & 0.845 & \\
\hline
\end{tabular}


Tabel 4 memperlihatkan kecendrungan penurunan kadar T3 terhadap peningkatan lama waktu (1, 2, 3 minggu) pada paparan zat pewarna erythrosine $1 \%$. Dari hasil uji statistic didapatkan nilai $\mathrm{P}=0.062(\mathrm{P}>0.05)$, ini menunjukkan penurunan kadar T3 tidak bermakna terhadap lama waktu paparan.

Tabel 5. Kadar T4 serum akibat paparan zat pewarna Erythrosine 300 ppm, 600 ppm hingga $1 \%$ dengan lama waktu konstan ( 3 minggu) pada tikus galur wistar.

\begin{tabular}{|c|c|c|c|c|c|}
\hline \multirow{2}{*}{ No. } & \multirow{2}{*}{ Kelompok } & \multicolumn{2}{|c|}{ Kadar T4 ( $\mu \mathrm{l} / \mathrm{dl})$} & \multirow{2}{*}{$\begin{array}{l}\text { Nilai Rata-rata } \\
\text { T4 ( } \mu \mathrm{l} / \mathrm{dl})\end{array}$} & \multirow[b]{2}{*}{$\mathbf{p}$} \\
\hline & & 1 & 2 & & \\
\hline 1. & Kontrol & 6.49 & 5.76 & 6.13 & \\
\hline 2. & E300 & 2.35 & 3.35 & 2.85 & \\
\hline 3. & E600 & 2.49 & 3.29 & 2.89 & 0.012 \\
\hline 4. & E1\% & 3.71 & 4.32 & 4.015 & \\
\hline
\end{tabular}

Tabel 5 memperlihatkan penurunan rerata T4 serum tikus akibat paparan erythrosine. Hasil analisis statistik Anova didapatkan nilai $\mathrm{p}=0,012(\mathrm{p}<0,05)$. Ini menunjukkan bahwa terdapat perbedaan bermakna antara kelompok kontrol $(\mathrm{K})$ terhadap kelompok perlakuan (300 ppm, 600 ppm dan 1\%). Analisis statistik dapat dilanjutkan dengan Post Hoc Tests Multiple Comparison

Tabel 6. Analisis Post Hoc Tests antara kelompok terhadap kadar T4 setelah pemberian Erythrosine

\begin{tabular}{cccc}
\hline Variabel & \multicolumn{2}{c}{ Kelompok } & p \\
\hline & Kontrol & E300 & 0.026 \\
& & E600 & 0,027 \\
Kadar T4 setelah & & E 1\% & 0,121 \\
pemberian Erythrosine & E300 & E600 & 1.000 \\
& & E 1\% & 0,647 \\
& E600 & E 1\% & 0.701 \\
\hline
\end{tabular}

Tabel 6 memperlihatkan bahwa terdapat perbedaan yang bermakna antara kontrol dengan paparan zat pewarna Erythtrosine 300 ppm dan 600 ppm $(\mathrm{p}<0,005)$ dan terdapat perbedaan yang tidak bermakna antara kontrol dengan pemberian Erythrosine 1\% (p >0.0,05) terhadap kadar T4.

Tabel 7. Kadar T4 serum akibat paparan zat pewarna Erythrosine 1\% dengan lama waktu yang bervariasi (1,2,3 minggu) pada tikus galur wistar.

\begin{tabular}{|c|c|c|c|c|c|}
\hline \multirow[t]{2}{*}{ No. } & \multirow[t]{2}{*}{ Kelompok } & \multicolumn{2}{|c|}{ Kadar T4 ( $\mu \mathrm{l} / \mathrm{dl})$} & \multirow{2}{*}{$\begin{array}{l}\text { Nilai Rata-rata } \\
\text { T4 ( } \mu \mathrm{l} / \mathrm{dl})\end{array}$} & \multirow[t]{2}{*}{$\mathbf{P}$} \\
\hline & & 1 & 2 & & \\
\hline 1. & Kontrol & 6.49 & 5.76 & 6.13 & \\
\hline 2. & E1 & 4.36 & 4.92 & 4.61 & \\
\hline 3. & E2 & 3.99 & 4.78 & 4.385 & 0.041 \\
\hline 4. & E3 & 3.71 & 4.32 & 4.01 & \\
\hline
\end{tabular}


Tabel 7 memperlihatkan kecendrungan penurunan kadar T4 terhadap peningkatan lama waktu (1, 2, 3 minggu) pada paparan zat pewarna erythrosine $1 \%$. Dari hasil uji statistic didapatkan nilai $\mathrm{P}=0.041(\mathrm{P}<0.05)$, ini menunjukkan bahwa terdapat penurunan kadar $\mathrm{T} 4$ secara bermakna terhadap lama waktu paparan.

Tabel 8. Analisis Post Hoc Tests antar kelompok terhadap kadar T4 pada variasi lama waktu (1, 2, 3 minggu)

\begin{tabular}{cccc}
\hline Variabel & \multicolumn{2}{c}{ Kelompok } & p \\
\hline & Kontrol & E1 & 0.219 \\
Kadar T4 variasi & & E2 & 0,133 \\
lama waktu paparan & E1 & E3 & 0,070 \\
& & E2 & 1.000 \\
& E2 & E3 & 1.000 \\
& E 3 & 1.000 \\
\hline
\end{tabular}

Tabel 8 memperlihatkan bahwa terdapat perbedaan yang bermakna antara kontrol dengan lama waktu pemaparan 3 minggu, dan terdapat perbedaan yang tidak bermakna antara kontrol dengan lama waktu pemaparan erythrosine 1 dan 2 minggu.

\section{Pembahasan}

Hasil penelitian yang telah dilakukan terdapat kecendrungan penurunan kadar T3 dan T4 serum tikus galur wistar bila dibandingkan terhadap kontrol. Kejadian ini dapat menunjukan sebagai indikasi hipotiroidisme. Hal ini disebabkan karena, zat pewarna sintetis erythrosine berdasarkan struktur kimia-nya terkandung senyawa yodium, maka dapat dikatakan secara substansial asupan makanan yang mengandung erythrosine merupakan asupan yodium. Penggunaan zat pewarna erythrosine dalam waktu lama dan kadar erythrosine diatas ambang batas tentu akan memberikan kontribusi kelebihan asupan yodium.

Kelebihan asupan yodium akan berdampak terhadap kadar T3 dan T4 dalam serum.
Erythrosine bila dilihat dari senyawa kimianya adalah 2-(6hidroxy-2,4,5,7-tetra iodo-3-okxoxanthen-9-yl). Dapat dikatakan asupan makanan dan obat-obatan yang mengandung erythrosine bisa berkontribusi secara substansial sebagai diet asupan yodium. Jika asupan yodium meningkat dan berlangsung kronik dapat mengindikasikan terjadinya hipotirodisme. Kadar optimal asupan yodium untuk mencegah kelainan tiroid merupakan rentangan yang sempit yaitu asupan yodium yang dianjurkan sehari berkisar $150 \mu \mathrm{g}$ untuk orang dewasa. Bahkan dengan iodisasi garam yang berhati-hatipun terjadi peningkatan insidence rate hipertirodisme. ${ }^{(6)}$

Hasil penelitian prospektif incidens hipertiroidisme dan hipotiroidisme yang nyata menunjukkan bahwa suplementasi iodium di masyarakat akan meningkatkan insinden hipotiroidisme, bahkan pada mayarakat dengan defisiensi idodium yang tingkatannya sedang. Pada populasi tesebut meningkatnya risiko hipotiroidisme harus dipertimbangkan terhadap risiko 
GAKI yaitu adanya hipertiroidisme akibat gondok multinodular toksik.

Kadar asupan iodium untuk mencegah penyakit tiroid mungkin merupakan rentangan yang sempit di sekitar jumlah asupan yodium yang dianjurkan sebanyak $150 \mu \mathrm{g}$ untuk orang dewasa. ${ }^{(6)}$

Pada binatang percobaan mem-perlihatkan hipotiroidisme akibat induksi iodium dan tak memperlihatkan adanya dasar autoimmune. ${ }^{(8)}$ Pada suatu penelitian berbasis populasi ternyata ditemukan insidens hipotiroidisme yang meningkat dengan bertambahnya asupan iodium. Hal ini karena sematamata disebabkan hipotiroidisme secara spontan. Kejadian hipotiroidisme yang jelas secara klinik relatif rendah di Denmark. ${ }^{(9)}$ Asupan iodium yang lebih dari adekuat atau berlebihan akan mengakibatkan hipotiroidisme dan tiroiditis autoimun. ${ }^{(10)}$

Jika asupan iodium meningkat dan berlangsung kronik, misalnya di daerah pantai di Jepang dan Cina yang disebabkan banyak makan ganggang laut, yang kaya akan iodium misalnya laminaria atau di Cina Timur yang disebabkan kandungan iodium tinggi dalam air minum dari sumur yang dangkal, prevalensi pembesaran tiroid (gondok) nya lebih tinggi dibandingkan dengan populasi normal dan prevalensi hipotiroidisme subklinik meningkat. ${ }^{(7)}$ Asupan iodium kronik sekitar 2 kali yang dianjurkan yang dinyatakan oleh konsentrasi iodium dalam urin dalam rentangan 300-500 $\mu \mathrm{g} / \mathrm{L}$ tak meningkatkan volume kelenjar tiroid pada anak.Tetapi bila iodium dalam urin $500 \mu \mathrm{g} / \mathrm{L}$ akan disertai peningkatan volume tiroid 1, yang merupakan dampak yang merugikan kelebihan iodium kronik. ${ }^{(11)}$

\section{Kesimpulan}

Berdasarkan hasil penelitian yang telah dilakukan dapat disimpulkan sebagai berikut :

1. Terdapat efek pemberian Erythrosine 300 ppm, 600ppm hingga $1 \%$ pada waktu 3 minggu terhadap kadar T3 dan T4 tikus galur wistar, yang secara statistic tedapat penurunan yang bermakna dengan $\mathrm{p}=0,018$ dan $\mathrm{p}=0,012$ bila dibandingkan dengan kontrol.

2. Tidak terdapat pengaruh lama waktu paparan zat pewarna erythrosine terhadap nilai $\mathrm{T} 3$ tikus Galur Wistar, yang secara statistic tidak terdapat penurunan yang bermakna dengan $\mathrm{p}=$ 0,062, bila dibandingkan terhadap kontrol.

3. Terdapat pengaruh lama waktu paparan zat pewarna erythrosine terhadap nilai T4 tikus Galur Wistar, yang secara statistic terdapat penurunan yang bermakna dengan $p=0,041$, bila disbanding-kan terhadap kontrol.

\section{Saran}

Perlu dilakukan penelitian lebih lanjut dengan variasi konsntrasi yang lebih banyak dan waktu yang lebih lama.

Murid SD umumnya mengkomsumsi makanan/minuman jajanan yang dijual disekitar sekolahnya. Oleh karena itu diperlukan peningkatan pengetahuan mereka tentang kesehatan khususnya mengenai penggunaan zat pewarna dalam makanan/minuman.

\section{KEPUSTAKAAN}

1. Cahyadi, Wisnu. 2006. Analisis dan Aspek Kesehatan Bahan Tambahan Makanan. Bumi Aksara. Jakarta. hal 1-2, 53-66. 
2. Irianto, Kus dan Kusno Waluyo. 2004. Gizi dan Pola Hidup Sehat. Penerbit CV.Yrama Widya. Bandung. hal 75-6.

3. Elmatris 2008. Analisis kualitatif dan Kuantitatif Zat Pewarna Pada Kripik Balado Yang Beredar di Bukittinggi., MKA. No.2, V01.32. JuliDesember 2008. hal 77-83.

4. Abdel Azis AH, Shouman SA,et al. A Study on The Reproductive Toxicity of Erythrosine in Male Mice. 1997. Pharmacol Res. 35(5).pages 457-62.

5. Anthony S.Jenings, Sorell L.Schwartz, et al.1990 .Effects of Oral Erythrosine (2',4,5',7'tetraiodo flurescein) on the Pituitary-Thyroid Axis in Rats. Toxicology an Applied Pharmacology. Vol.103. Issue 3. pages 549-56.

6. Bülow Pedersen I, Knudsen N, Jørgensen T, Perrild H, Ovesen L, Laurberg P 2002. Large differences in incidences of overt hyper- and hypotiroidism associated with a small difference in iodium intake; a prospective comparative register-based population survey. J Clin Endocrinol Metab 87: 4462-9. yang dikutip dari Laporan Penelitian Lapangan tentang Kasus Ekses Yodium di Masyarakat Karena pemberian Kapsul Yodium dan Garam Beryodium oleh Dr. dr. Sartono, Sp.A(K), Sp.GK.
7. Delange,F., and Hetzel,B. 2006 Chapter 20 By Mastorakos,G., Nezi, M., and Papadopoulos,C. The Iodium Deficiency Disorders Tiroid Manager. The Tiroid and its Diseases. Updated: July 29, 2006., yang dikutip dari Laporan Penelitian Lapangan tentang Kasus Ekses Yodium di Masyarakat Karena pemberian Kapsul Yodium dan Garam Beryodium oleh Dr. dr. Sartono, Sp.A(K), Sp.GK.

8. Li,H.S., and Carayanniotis,G., 2007. Induction of Goitrous Hypotiroidism by Dietary Iodide in SJL Mice. Endocrinology 148: 27472752. yang dikutip dari Laporan Penelitian Lapangan tentang Kasus Ekses Yodium di Masyarakat Karena pemberian Kapsul Yodium dan Garam Beryodium oleh Dr. dr. Sartono, Sp.A(K), Sp.GK.

9. Carle' A, Laurberg P, Bu“ low Pedersen I, Knudsen N, Perrild $\mathrm{H}$, Ovesen L, Rasmussen LB, Jørgensen T 2006. Epidemiology of subtypes of hypotiroid-ism in Denmark. Eur J Endocrinol 154: 21-8. yang dikutip dari Laporan Penelitian Lapangan tentang Kasus Ekses Yodium di Masyarakat Karena pemberian Kapsul Yodium dan Garam Beryodium oleh Dr. dr. Sartono, Sp.A(K), Sp.GK.

10. Teng W, Shan $Z$, Teng $X$, Guan H, Li Y, Teng D, Jin Y, Yu X, Fan C, Chong W, Yang F, Dai H, Yu Y, Li J, Chen Y, Zhao D, Shi X, Hu F, Mao J, 
Gu X, Yang R, Tong Y, Wang W, Gao T, Li C 2006. Effect of iodium intake on tiroid diseases in China. $\mathrm{N}$ Engl $\mathrm{J}$ Med 354: 2783-93. yang dikutip dari Laporan Penelitian Lapangan tentang Kasus Ekses Yodium di Masyarakat Karena pemberian Kapsul Yodium dan Garam Beryodium oleh Dr. dr. Sartono, Sp.A(K), Sp.GK.
11. Zimmerman, D and Bryant, W.P., 1995. Iodium-Induced Hypertiroidism in a Newborn. Pediatrics; 95; 434-6. yang dikutip dari Laporan Penelitian Lapangan tentang Kasus Ekses Yodium di Masyarakat Karena pemberian Kapsul Yodium dan Garam Beryodium oleh Dr. dr. Sartono, Sp.A (K), Sp.GK. 